Article

\title{
Distribution of Foliicolous Lichen Strigula and Genetic Structure of S. multiformis on Jeju Island, South Korea
}

\author{
Seung-Yoon $\mathrm{Oh}^{1}{ }^{\mathbb{D}}$, Jung-Jae Woo ${ }^{1,2}$ and Jae-Seoun Hur ${ }^{1, *}$ \\ 1 Korean Lichen Research Institute, Sunchon National University, 255 Jungang-Ro, Suncheon 57922, Korea; \\ syoh@snu.ac.kr (S.-Y.O.); lichenwoojae@korea.kr (J.-J.W.) \\ 2 Division of Forest Biodiversity, Korea National Arboretum, 415 Gwangneungsumok-ro, \\ Pocheon 11186, Korea \\ * Correspondence: jshur1@scnu.ac.kr; Tel.: +82-61-750-3383
}

Received: 3 August 2019; Accepted: 8 October 2019; Published: 10 October 2019

\begin{abstract}
Strigula is a pantropic foliicolous lichen living on the leaf surfaces of evergreen broadleaf plants. In South Korea, Strigula is the only genus of foliicolous lichen recorded from Jeju Island. Several Strigula species have been recorded, but the ecology of Strigula in South Korea has been largely unexplored. This study examined the distribution and genetic structure of Strigula on Jeju Island. The distribution was surveyed and the influence of environmental factors (e.g., elevation, forest availability, and bioclimate) on the distribution was analyzed using a species distribution modeling analysis. In addition, the genetic variations and differentiation of Strigula multiformis populations were analyzed using two nuclear ribosomal regions. The distribution of Strigula was largely restricted to a small portion of forest on Jeju Island, and the forest availability was the most important factor in the prediction of potential habitats. The genetic diversity and differentiation of the S. multiformis population were found to be high and were divided according to geography. On the other hand, geographic and environmental distance did not explain the population differentiation. Distribution and population genetic analysis suggested that the available habitat and genetic exchange of Strigula on Jeju Island are limited by the lack of available forest in the lowlands.
\end{abstract}

Keywords: Dothideomycetes; foliicolous lichen; gene flow; Jeju Island; lichens; MaxEnt; population genetics; species distribution modeling; Strigula multiformis

\section{Introduction}

Foliicolous lichens are an ecological group of lichens living on the surface of plant leaves [1]. More than 800 species of foliicolous lichens have been found worldwide. They are distributed generally in subtropical and tropical forests and play important ecological roles in forest ecosystems [2]. The distribution and genetic variations of foliicolous lichens have received less attention than other lichen groups, likely due to their small and inconspicuous morphology [3,4]. Various environmental factors, such as climate, elevation, and vegetation are associated with the lichen distribution [5-9]. Therefore, an understanding of the relationship between environmental factors and lichen occurrence is key to identifying and predicting the distribution of lichens [10]. In addition, the genetic variations of the lichen population are important because they are a source of environmental adaptation [11]. A loss of genetic variation reduces the adaptive potential against environmental stress, such as climate change and habitat disturbance [12,13]. Similar to the distribution pattern, the geographic condition, climate, and vegetation can influence the genetic structure of lichen populations [14-19]. Knowledge of distribution and genetic variations can help better understand the basic ecology of foliicolous lichens as well as the fundamental aspects of the conservation strategy. 
In South Korea, only one genus of foliicolous lichen, Strigula, has been recorded from Jeju Island [20]. Jeju Island is located in the southernmost area of South Korea and has the warmest conditions, i.e., a subtropical climate [21]. In addition, the vegetation is different from that of the Korean mainland, which is composed of temperate-subtropical vegetation. This climate and these vegetation conditions allow foliicolous lichens to live on Jeju Island [20]. Recently, a study using molecular phylogeny showed that two novel Strigula exist [22]. Among them, Strigula multiformis (Mycobank number: MB831530) is the most common species on Jeju Island. This species has been mistaken for Strigula smaragdula in South Korea based on their similar morphology, but both the molecular and morphological characteristics of S. multiformis can be used to distinguish it from S. smaragdula [22]. Although it has distinct characteristics compared to other groups of lichens, the ecology of Strigula has been largely unexplored. Given that Jeju Island is the optimal habitat of foliicolous lichens in South Korea, the distribution and the genetic structure of Strigula on Jeju Island need to be investigated to better understand the basic biology as well as the conservation practice of foliicolous lichens in South Korea.

This study examined the distribution and genetic structure of Strigula on Jeju Island. In addition, we hypothesized that environmental factors influence the distribution and genetic structures of Strigula populations. Specifically, this study had two objectives. First, the distribution of Strigula was surveyed on the whole island, and species distribution modeling (SDM) analysis was performed to identify potential habitats and the influence of environmental factors (bioclimatic variables, elevation, and vegetation) on the distribution of Strigula. Second, the genetic structure of S. multiformis was analyzed using a nuclear ribosomal internal transcribed spacer (ITS) and partial large subunit (LSU) region, and the effects of environmental factors on the genetic structures were analyzed focusing on the geographic distance, climate, and vegetation.

\section{Materials and Methods}

\subsection{Sample Collection and Distribution Analysis}

Jeju Island was chosen as a study area due to its distinctive properties as a Strigula habitat. Although Strigula is generally a pantropical species [2], Jeju Island is located in one of the two coldest areas in Eastern Asia where Strigula species are found (i.e., Korea and Japan) [20,23]. It is the closest region to the mainland of South Korea where no foliicolous lichen have been found [20], which suggests that Jeju Island can be a source of a population when Strigula disperses to the mainland of the Korean peninsula. In addition, two Strigula species on Jeju Island have been newly described in scientific literature [22]. These species may be endemic to South Korea and the knowledge of these species is very limited; thus, the ecology of these species needs to be elucidated before expanding the study to a worldwide scale. Sampling was conducted on Jeju Island during June-July and November in 2018. For describing the distribution of Strigula, an island-wide survey for the forests covering the whole island where Strigula can live was performed to confirm the previous records and expand the records of Strigula habitats. The specimen records from the Korean Lichen Research Center (KoRLI) (2012-2014) and previous studies [20] were used to survey Strigula occurrence. The leaves were thoroughly examined to detect Strigula (Figure 1), and species were identified morphologically based on previous studies [2,22]. For population genetic analysis, a total of five forests where S. multiformis was abundant were chosen to obtain a sufficient number of specimens (Table 1). The leaves with the thalli of S. multiformis were collected from a total of six tree stands for each forest. 


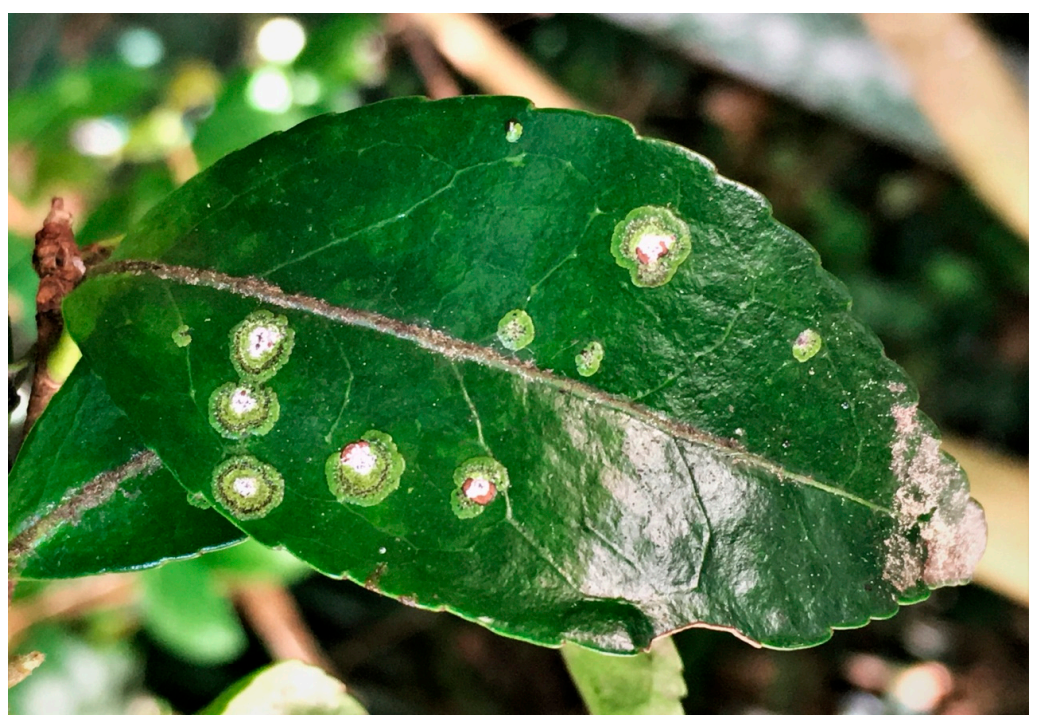

Figure 1. Strigula multiformis on the leaf of Camellia japonica. Photograph by Jung-Jae Woo.

Table 1. List of locations where Strigula species have been detected.

\begin{tabular}{|c|c|c|c|c|}
\hline No. & Locality (Code) & GPS & Elev. (m) & Species Detected \\
\hline 1 & Andeok Valley (AD)* & $33^{\circ} 15^{\prime} 23.06^{\prime \prime} \mathrm{N}, 126^{\circ} 21^{\prime} 16.61^{\prime \prime} \mathrm{E}$ & 33-124 & S. multiformis \\
\hline 2 & Bija forest & $33^{\circ} 29^{\prime} 27.45^{\prime \prime} \mathrm{N}, 126^{\circ} 48^{\prime} 34.27^{\prime \prime} \mathrm{E}$ & $131-170$ & S. depressa, S. multiformis \\
\hline 3 & Camellia hill & $33^{\circ} 17^{\prime} 28.56^{\prime \prime} \mathrm{N}, 126^{\circ} 22^{\prime} 25.96^{\prime \prime} \mathrm{E}$ & $262-263$ & S. depressa \\
\hline 4 & Cheongsu Gotjawal & $33^{\circ} 18^{\prime} 09.29^{\prime \prime} \mathrm{N}, 126^{\circ} 16^{\prime} 20.93^{\prime \prime} \mathrm{E}$ & $115-134$ & S. multiformis \\
\hline 5 & Cheonjaeyeon & $33^{\circ} 15^{\prime} 08.43^{\prime \prime} \mathrm{N}, 126^{\circ} 25^{\prime} 01.59^{\prime \prime} \mathrm{E}$ & 45 & S. multiformis \\
\hline 6 & Cheonjiyeon (CJ) & $33^{\circ} 14^{\prime} 43.93^{\prime \prime} \mathrm{N}, 126^{\circ} 33^{\prime} 30.58^{\prime \prime} \mathrm{E}$ & $6-32$ & S. multiformis \\
\hline 7 & Dongbaek hill (DB) & $33^{\circ} 30^{\prime} 49.5^{\prime \prime} \mathrm{N}, 126^{\circ} 42^{\prime} 36.24^{\prime \prime} \mathrm{E}$ & $77-122$ & S. multiformis \\
\hline 8 & Eongtto waterfall & $33^{\circ} 16^{\prime} 03.45^{\prime \prime} \mathrm{N}, 126^{\circ} 29^{\prime} 53.59^{\prime \prime} \mathrm{E}$ & 185 & S. depressa \\
\hline 9 & Hwan-Sang Forest & $33^{\circ} 19^{\prime} 24.54^{\prime \prime} \mathrm{N}, 126^{\circ} 15^{\prime} 52.89^{\prime \prime} \mathrm{E}$ & $132-141$ & S. depressa, S. multiformis \\
\hline 10 & Jeoji Gotjawal (JJ) & $33^{\circ} 17^{\prime} 14.30^{\prime \prime} \mathrm{N}, 126^{\circ} 16^{\prime} 12.81^{\prime \prime} \mathrm{E}$ & $91-167$ & S. depressa, S. multiformis \\
\hline 11 & Nabeup forest (NE) & $33^{\circ} 26^{\prime} 02.99^{\prime \prime} \mathrm{N}, 126^{\circ} 19^{\prime} 46.86^{\prime \prime} \mathrm{E}$ & $89-97$ & S. depressa, S. multiformis \\
\hline 12 & Won-ang Waterfall & $33^{\circ} 18^{\prime} 02.47^{\prime \prime} \mathrm{N}, 126^{\circ} 34^{\prime} 46.11^{\prime \prime} \mathrm{E}$ & 287 & S. multiformis \\
\hline
\end{tabular}

The locations used for population genetic analysis are presented in bold and the population code is provided in parentheses.

SDM analysis is the method to predict the distribution and suitable habitat conditions based on species distribution records and environmental variables [24]. Among various algorithms of SDM analysis, maximum entropy modeling (MaxEnt) has shown high performance of model prediction, even with small numbers of occurrence data [25-27]; thus, it was used to predict potential habitat distribution of Strigula species on Jeju Island. The climate, elevation, and forest availability were used as environmental variables. Nineteen sets of bioclimate data were acquired from the WorldClim database v. 2 [28] as a high-resolution dataset (30 arc-seconds) (Table A1). To avoid overfitting the model due to multicollinearity among climate variables, the variables were reduced using a stepwise backward variable selection procedure based on the variance inflation factor (VIF $<10$ ), using the usdm package [29]. Elevation data were acquired as digital elevation model (DEM) data from the NASA shuttle radar topographic mission (SRTM) dataset [30]. Vegetation distribution and type information (1:5000 resolution) were acquired from the forest geographic information system (FGIS) operated by the Korea Forest Service. The forest availability was filtered based on the forest type and composition to cover the possible host plants of Strigula (evergreen broadleaves or mixed forest). Preprocessing of the geographical raster and vector data was conducted using gstudio [31], raster [32], and rgdal [33] packages in R v. 3.5.1 [34], and QGIS v. 3.6 [35]. SDM analysis was performed based on the Strigula occurrence records and environmental variables using MaxEnt v 3.3.3 [36], implemented in $\mathrm{R}$ package dismo [28] with a maximum of 10,000 background points and a maximum of 500 iterations. The accuracy of the model was evaluated based on the area under the curve (AUC) of the receiving 
operator curve (ROC). AUC values of more than $0.9,0.7-0.9$, and $0.5-0.7$ indicated high, moderate, and low model accuracy, respectively $[37,38]$. The contribution of an environmental variable to predict the model was measured using the jackknife test. The final model was constructed after removing the low contribution $(<1 \%)$ variables.

\subsection{Molecular Experiments}

A total of 3-5 thalli from each tree stand were used in the analyses. From each leaf specimen, a single thallus was collected to avoid possible clonal strains living together on the same leaf surface. The genomic DNA was extracted from a thallus of S. multiformis using a modified cetyltrimethylammonium bromide (CTAB) method [39]. Since genomic DNA can contain the DNA from other organisms (e.g., host plant, alga, or other fungi), a specific primer (Strig1F, 5-AGSWGCTTAAGATATGGTCG-3) for S. multiformis and its close Strigula species was developed on the intron site between the ITS5 and ITS1 primer positions [40], using the Strigula sequences from GenBank (KF553661-KF553664, MK118870-MK118879). The ITS region was amplified using ITS5/ITS4 or Strig1F/ITS4 [39], and the LSU region was amplified using LROR/LR5 or Strig1F/LR5 [41]. The host plant was identified based on the morphological characteristics and confirmed based on the chloroplast gene for morphological representative samples chosen from each location. The chloroplast maturase $\mathrm{K}$ (matK) or ribulose bisphosphate carboxylase large chain (rbcL) was amplified using matK-390F/matK-1326R [42] and rbcL-1F/rbcL-724R [43] primers, respectively. PCR amplification was performed using AccuPower PCR premix (Bioneer, Daejeon, South Korea) under the following conditions: $95^{\circ} \mathrm{C}$ for $5 \mathrm{~min}, 35$ cycles of $95{ }^{\circ} \mathrm{C}$ for $40 \mathrm{~s}, 55^{\circ} \mathrm{C}$ for $40 \mathrm{~s}, 70{ }^{\circ} \mathrm{C}$ for $1 \mathrm{~min}$, and a final extension at $70^{\circ} \mathrm{C}$ for $10 \mathrm{~min}$. Sequencing was conducted using the PCR primer sets on an ABI Prism 3730xl analyzer (Applied Biosystems, Foster city, CA, USA) from Macrogen (Seoul, South Korea). The sequences were checked and edited in MEGA v. 5 [44] and aligned using MAFFT v. 7 [45]. All sequences generated in this study were deposited at GenBank under accession numbers of MN097373-MN097492 for ITS, MN097248-MN097367 for LSU region, and MN103855-MN103866 for the plant chloroplast genes.

\subsection{Population Genetic Analysis}

The genetic variations of $S$. multiformis populations were calculated for the number of variation sites $(S)$, nucleotide diversity $(\pi)$, number of haplotypes $(h)$, and haplotype diversity (Hd) using DnaSP v. 6 [46]. Prior to analysis, the ITS region was filtered by extracting the partial $18 S$ and LSU region using ITSx v. 1.1 [47]. For the LSU region, the sequence showing a large insertion/deletion (indel) site (58 bp) can result in an over- or underestimation of the genetic diversity of populations. Thus, the sequence of the indel site was imposed based on the most common haplotype (haplotype H01) after adding one nucleotide difference representing an indel event. The haplotype network was generated to determine the relationship between the haplotypes using PopART v. 1.7 [48] based on the TCS method [49]. The demographic history of the population was analyzed using a neutrality test based on Tajima's D using the DnaSP. A D value near zero indicates neutrality and equilibrium, whereas a significantly high value implies a recent population contraction or balancing selection [50].

The genetic differentiation of the populations was examined using a pairwise $\phi_{\text {st }}$ and tested for geographic groups and host plant groups by Analysis of Molecular Variance (AMOVA) using Arlequin v. 3.5 with the option of "compute distance matrix" [51]. The sequences from the same tree stands were grouped as a subpopulation. Discriminant analysis of the principal components (DAPC) was conducted to detect the population structures [52]. This method is similar to STRUCTURE analysis, while it has no assumption of independence between loci. The clustering of individual sequences was performed from k-means clustering, and the number of the cluster was determined based on the Bayesian information criterion (BIC). All analyses associated with DAPC were conducted using the adegenet package [53]. The isolation by distance (IBD) pattern was tested using a simple Mantel test on the vegan package [54] based on geographic distance and genetic distances. Slatkin's distance $\left(\phi_{\text {st }} /(1\right.$ 
$\left.-\phi_{\mathrm{st}}\right)$ ) [55] was calculated for the genetic distance. The isolation by environment (IBE) pattern was analyzed for the elevation and Bioclim variables using a simple Mantel test.

\section{Results}

\subsection{Distribution and Potential Habitat of Strigula}

A total of 12 forests were confirmed to have Strigula (Figure 2a; Table 1). The bioclimatic variables were selected prior to SDM analysis. Among 19 variables, six variables remained for analysis: BIO01 (Annual mean temperature), BIO03 (Isothermality), BIO07 (Temperature annual range), BIO12 (Annual precipitation), BIO14 (Precipitation of the driest month), and BIO15 (Precipitation seasonality) (Figure A1). In the initial model, BIO1, BIO3, BIO7, BIO12, and BIO15 made a low contribution to predicting the Strigula distribution; thus, they were excluded from the final model. A best-fit model containing BIO14, elevation, and forest availability showed high predictive accuracy (AUC $=0.902$ ) (Figure $2 b$ ). The forest availability made the highest contribution $(67.8 \%)$, followed by elevation $(20.8 \%)$ and BIO14 (11.4\%). The predicted suitable habitat existed in evergreen broadleaves or mixed forest (Figure 2a). The total forest area of Jeju Island was calculated to be 62,531 ha, and the area of evergreen broadleaves or mixed forest was $23.3 \%$ of the total forest (14,577 ha). In the case of elevation, the low-elevation areas $(<500 \mathrm{~m})$ were predicted to be a better habitat. The probability of Strigula occurrence decreased with the increasing amount of precipitation in the driest month (BIO14).
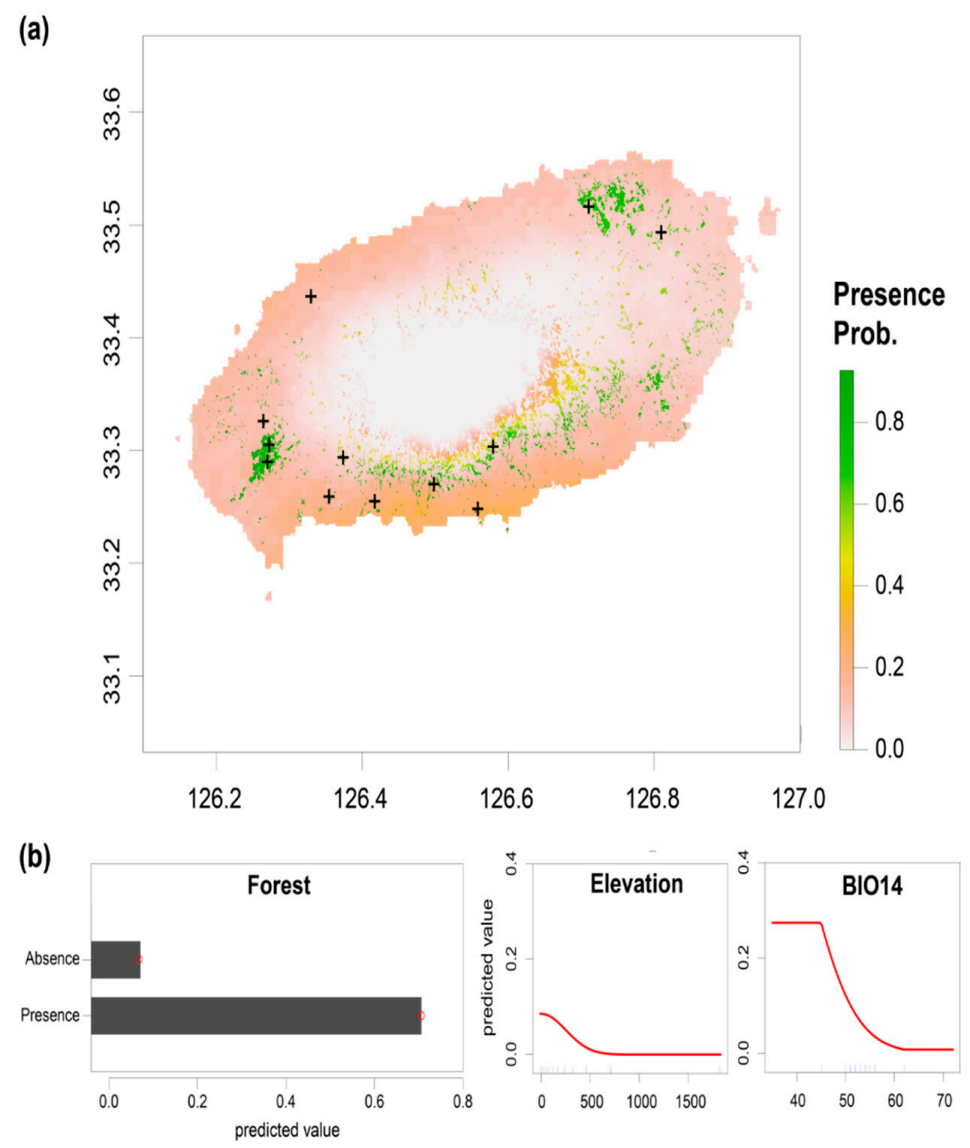

Figure 2. Distribution and potential habitat prediction of Strigula on Jeju Island. (a) Strigula distribution and potential habitats predicted by MaxEnt. The highest probability of its presence is indicated as green. A cross sign indicates the location of Strigula occurrence recorded by survey. (b) Response plot of environmental variables contributing to the model prediction of species distribution modeling (SDM) analysis. 


\subsection{Genetic Diversity of S. multiformis Populations}

A total of 120 thalli of S. multiformis collected from five forests on Jeju Island were analyzed using the ITS and LSU regions. The length of alignment and number of segregating sites were $469 \mathrm{bp}$ and 12 for the ITS region, and $906 \mathrm{bp}$ and 15 for the LSU region, respectively. The nucleotide diversity was higher in the ITS regions than in the LSU region. In total, 19 ITS haplotypes and 17 LSU haplotypes were found (Table 2). The most common ITS haplotype was H01 with four populations (17 thalli), followed by $\mathrm{H} 13$ belonging to DB and NE populations (31 thalli) (Figure 3a). In the case of the LSU haplotype, haplotype $\mathrm{H} 07$, belonging to DB and NE populations (34 thalli), was the most common, followed by $\mathrm{H} 01$ with four populations (30 thalli) (Figure 3b). The LSU haplotypes, H02 and H03, had large indel ( $58 \mathrm{bp}$ ) near the LR5 primer site, and they belonged mostly to the AD population except for a thallus from the JJ population. Population-specific haplotypes were detected in 15 haplotypes for the ITS regions (71.4\%) and 11 haplotypes for the LSU regions (68.8\%), and they comprised 38.3\% and $20.8 \%$ of thalli, respectively. In the case of the haplotypes shared among multiple populations, one population covered the highest proportions $(\geq 50 \%)$. All populations showed no selection and a constant population size by an estimate of Tajima's D, except for the CJ population (Table 2). The ITS region in the CJ population showed a significantly high Tajima's D value, which suggests that the selection pressure or recent population had decreased; the LSU region of the CJ population also showed a high value but it was not significant (Table 2).

\section{(a)}

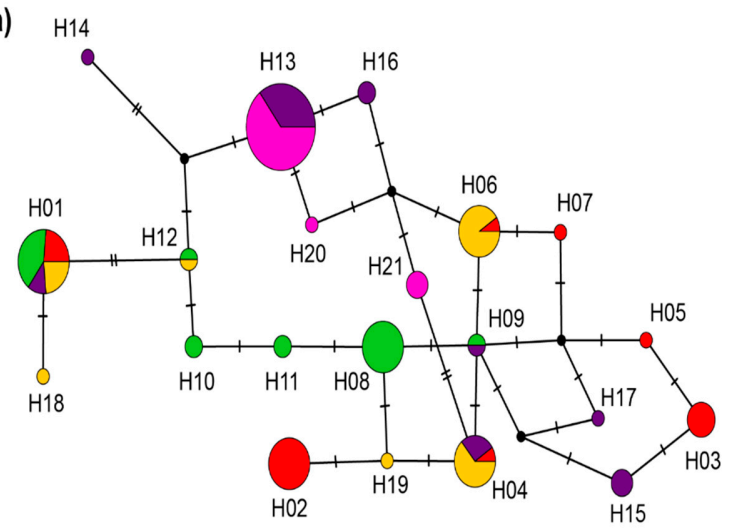

(b)

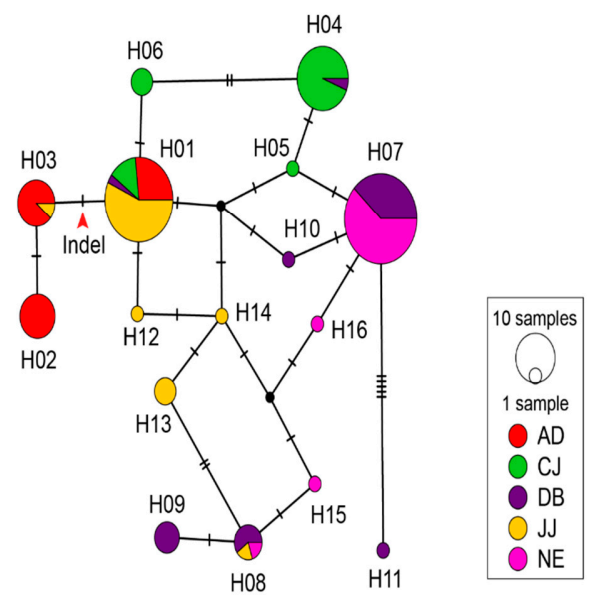

Figure 3. Haplotype networks for (a) the ITS and (b) the LSU region of the S. multiformis populations. The size of the pie chart is proportional to the number of thalli belonging to the haplotype, and the color is according to the geographic populations. The dash on the line represents one mutational step of the haplotype sequence. The red arrow in the LSU network indicates an insertion/deletion (indel) event. 
Table 2. Summary of the genetic diversity statistics of internal transcribed spacer (ITS) and large subunit (LSU) regions of $S$. multiformis populations.

\begin{tabular}{cccccccc}
\hline Marker & Population & $\mathbf{n}$ & $\mathbf{S}$ & $\mathbf{h}$ & $\mathbf{H d}$ & $\boldsymbol{\pi}$ & $\mathbf{D}$ \\
\hline ITS & AD & 24 & 9 & 7 & 0.743 & 0.00811 & 1.39443 \\
& CJ & 24 & 5 & 6 & 0.717 & 0.00509 & 2.25414 \\
& DB & 24 & 10 & 8 & 0.772 & 0.00754 & 1.06039 \\
& JJ & 24 & 8 & 6 & 0.739 & 0.00557 & 0.69848 \\
& NE & 24 & 3 & 3 & 0.301 & 0.00159 & -0.17843 \\
& Total & 120 & 13 & 21 & 0.882 & 0.00877 & 1.5262 \\
LSU & AD & 24 & 2 & 3 & 0.696 & 0.00102 & 1.60933 \\
& CJ & 24 & 3 & 4 & 0.533 & 0.00133 & 1.26224 \\
& DB & 24 & 12 & 7 & 0.685 & 0.00305 & -0.47932 \\
& JJ & 24 & 6 & 6 & 0.496 & 0.00141 & -0.62373 \\
& NE & 24 & 4 & 4 & 0.239 & 0.00070 & -1.12525 \\
& Total & 120 & 14 & 16 & 0.829 & 0.00310 & 0.20223 \\
\hline
\end{tabular}

ITS: internal transcribed spacer, LSU: large subunit, n: number of thalii, S: number of variation sites, h: number of haplotypes, Hd: the haplotype diversity, $\pi$ : nucleotide diversity, D: Tajima's D (*: $p<0.05)$.

\subsection{Genetic Structure of S. multiformis Populations}

The genetic structure of $S$. multiformis populations was analyzed for the geography and host plant groups using AMOVA (Table 3). For the geographical group, all fixation indices were significant for both the ITS and LSU regions $(p<0.01)$. The high amount of variation was explained by the geographical groups (ITS: $39.7 \%$, LSU: $55.6 \%$ ), whereas the difference in the thalli within the subpopulation (tree stand) also explained the significant variations (ITS: $47.2 \%$, LSU: $35.2 \%$ ). The subpopulation difference within the geographical group had a low contribution to the genetic structure (ITS: 13.2\%, LSU: 9.2\%). For the host plant group, the fixation indices for the different groups were not significant for both the ITS $(p=0.548)$ and LSU $(p=0.126)$. The contribution of the host plant group on explaining the genetic variation was extremely low (ITS: $-2.1 \%$, LSU: $5.8 \%$ ).

Table 3. Analysis of molecular variance (AMOVA) results for the ITS and LSU regions of S. multiformis populations. The asterisk indicates a significant fixation index $\left(^{* *}: p<0.01,{ }^{* * *}: p<0.001\right)$.

\begin{tabular}{|c|c|c|c|c|c|c|}
\hline Group & Source of Variance & d.f. & $\begin{array}{c}\text { Sum of } \\
\text { Squares }\end{array}$ & $\begin{array}{c}\text { Variance } \\
\text { Components }\end{array}$ & $\begin{array}{c}\% \text { of } \\
\text { Variation }\end{array}$ & $\begin{array}{c}\text { Fixation } \\
\text { Indices }\end{array}$ \\
\hline ITS & & & & & & \\
\hline \multirow[t]{4}{*}{ Geography } & Between groups & 4 & 94.025 & 0.885 & 39.7 & $0.397^{* * *}$ \\
\hline & Among subpop. & 25 & 55.442 & 0.293 & 13.1 & $0.218^{* * *}$ \\
\hline & Within subpop. & 90 & 94.767 & 1.053 & 47.2 & $0.528 * * *$ \\
\hline & Total & 119 & 244.233 & 2.231 & & \\
\hline \multirow[t]{4}{*}{ Host } & Between groups & 2 & 7.789 & -0.043 & -2.1 & -0.021 \\
\hline & Among subpop. & 27 & 141.677 & 1.048 & 51.0 & $0.499 * * *$ \\
\hline & Within subpop. & 90 & 94.767 & 1.053 & 51.2 & $0.488^{* * *}$ \\
\hline & Total & 119 & 244.233 & 2.058 & & \\
\hline \multirow{5}{*}{ Geography } & & & & & & \\
\hline & Between groups & 4 & 88.917 & 0.878 & 55.6 & $0.556^{* * *}$ \\
\hline & Among subpop. & 25 & 28.317 & 0.145 & 9.2 & $0.208^{* *}$ \\
\hline & Within subpop. & 90 & 49.933 & 0.555 & 35.2 & $0.648^{* * *}$ \\
\hline & Total & 119 & 167.167 & 1.578 & & \\
\hline \multirow[t]{4}{*}{ Host } & Between groups & 2 & 12.482 & 0.086 & 5.8 & 0.058 \\
\hline & Among subpop. & 27 & 104.751 & 0.830 & 56.5 & $0.599 * * *$ \\
\hline & Within subpop. & 90 & 49.933 & 0.555 & 37.7 & $0.623^{* * *}$ \\
\hline & Total & 119 & 167.167 & 1.471 & & \\
\hline
\end{tabular}

A high level of differentiation for geographical populations was detected from the high values of pairwise $\phi_{\text {st }}$ for both the ITS and LSU regions (Table 4). The values of pairwise $\phi_{\text {st }}$ indicated that the population differentiation was high (ITS: $0.148-0.738$, LSU: $0.114-0.817)$ and significant $(p<0.05)$. For the ITS region, the lowest $\phi_{\text {st }}$ value was detected between the Andeok Valley (AD) and Cheonjiyeon 
(CJ) populations (0.171) and the AD and Jeoji Gotjawal (JJ) populations (0.148). For the LSU region, the Dongbaek hill (DB) and Nabeup forest (NE) populations had the lowest value (0.114).

Table 4. Pairwise $\phi_{\text {st }}$ for five populations of $S$. multiformis. The results from the ITS and LSU regions are on the lower and upper triangular matrix, respectively. All values are statistically significant $(p<0.05)$.

\begin{tabular}{cccccc}
\hline & AD & CJ & DB & JJ & NE \\
\hline AD & 0 & 0.667 & 0.615 & 0.350 & 0.817 \\
CJ & 0.171 & 0 & 0.394 & 0.523 & 0.650 \\
DB & 0.320 & 0.386 & 0 & 0.468 & 0.114 \\
JJ & 0.148 & 0.201 & 0.236 & 0 & 0.720 \\
NE & 0.648 & 0.738 & 0.213 & 0.641 & 0 \\
\hline
\end{tabular}

DAPC analysis showed that four genetic clusters existed in the total population of S. multiformis (Figure $4 \mathrm{a})$. All individuals had a high probability of membership to each cluster $(>90 \%)$. The composition of genetic clusters was divided geographically into northern (NE and DB) and southern (AD, CJ, and JJ) regions (Figure $4 \mathrm{~b}$ ). For the northern region, cluster 4 was composed of the highest proportions ( $>56 \%$ ). Cluster 1 was more common in the southern regions ( $\mathrm{AD}, \mathrm{CJ}$, and JJ) than in the northern regions. In the southern regions, the proportion of cluster 3 increased along the eastern side from CJ to the JJ population. Cluster 2 was most common in the $\mathrm{AD}$ and CJ populations.

(a)

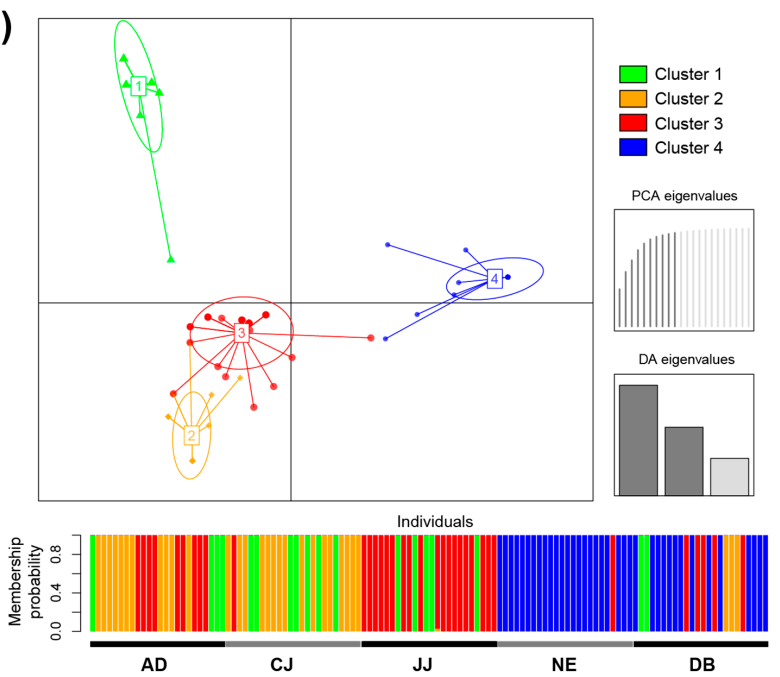

(b)

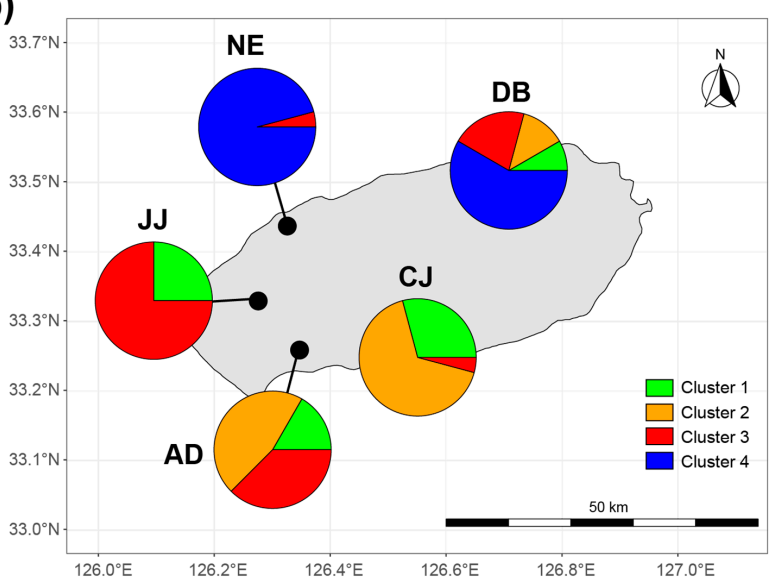

Figure 4. Genetic structure of $S$. multiformis populations based on discriminant analysis of the principal components (DAPC). (a) Scatter and membership plot for the DAPC clusters. (b) Distribution map of DAPC clusters at each population. The clusters are coded by colors and their size is proportional to the number of thalli ( $n=25 /$ each population). 
The IBD and IBE patterns were analyzed using a Mantel test. The geographic distance did not show a significant relationship with the genetic distances (ITS: $\mathrm{r}=-0.217, p=0.717$, LSU: $\mathrm{r}=-0.374, p$ $=0.825)$. The IBE pattern was tested for the elevation and Bioclim variables (BIO1, BIO3, BIO7, BIO12, BIO14, BIO15), whereas no significant relationship was detected between any of the environmental variables and genetic distances.

\section{Discussion}

The distribution of Strigula species was examined and Strigula was found only in 12 forests on Jeju Island (Figure 2), which suggests that Strigula species are rare and restricted to a small portion of the area on Jeju Island. Lichen distribution is influenced by a range of environmental factors, such as climate [5,56], vegetation [8], host plant physiology [57], soil physiochemistry [58], land use [59], and concentration of pollutants [60,61]. For Strigula species, host availability can be one of the most important factors to the establishment of forests because foliicolous lichen can live on the surface of host leaves [2]. Strigula are generally found on the leaves of evergreen broadleaf plants [3,62]. In South Korea, Camellia japonica, Litsea spp., Machilus spp., and Quercus acuta are known as the host plants of Strigula [20,22]; thus, Strigula occurs in evergreen broadleaved forests or mixed forests, where the host plant exists. Among the total area of Jeju Island (ca. 180,000 ha), forest covers 34.1\% (ca. 62,000 ha) and most of the forest is located on Mt. Halla, where the elevation is high. Considering the forest type and composition, the potential habitat of Strigula is only $8.0 \%$ of the total area of the island. The SDM analysis supports the importance of host plant presence for Strigula distribution. The contribution of the model prediction was highest for the forest availability (Figure 2b). The importance of the forest structure for lichen communities is well known, particularly for epiphyte lichens [8,63,64], and similar characteristics were also found in foliicolous lichen [65].The elevation is the second largest contributing factor to the distribution of Strigula (Figure 2b). Strigula was found in the lowland forest where the elevation is low (Table 1). On Jeju Island, Mt. Halla is located in the center of the island, and the elevation decreases toward the coast. Strigula was not found on Mt. Halla and was only found in lowland forest (6-287 m), which agrees with the previous study that the community of foliicolous lichens is different depending on the elevation and tends to favor lowland areas [23,65]. Precipitation also contributes to the potential distribution of Strigula in that Strigula occurred in areas with low precipitation in the driest month (Figure 2b). Given the worldwide distribution of Strigula in a tropical forest, Strigula is expected to favor high precipitation, but the model prediction showed an opposite trend. The mechanism of the precipitation effect on the Strigula distribution is unclear and needs to be elucidated. In this study, SDM analysis was performed based on a small number of Strigula records from a limited area, which suggests that caution should be exercised when the results from our SDM analysis are interpreted. Although MaxEnt is relatively robust, a small dataset can make biased models and reduce the accuracy of prediction [24,26]. To obtain a more reliable model of Strigula distribution, therefore, further study needs to be conducted using an increased number of occurrence records from an expanded study area.

Two of the nuclear ribosomal DNA regions showed genetic variations well within and between $S$. multiformis populations. The ITS and LSU regions are used frequently for phylogenetic and population genetic analysis, and many lichen species showed high variations in these regions $[15,17,18,66]$. In this study, the ITS and LSU region showed a high level of genetic diversity, which concurs with previous studies [17,66-68]. The number of population-specific haplotypes was high in both ITS and LSU regions (Figure 3). In the case of haplotypes shared among populations, they had an uneven proportion biased to a specific population; more than half of thalli in the haplotype were from a single population. Most populations showed a similar level of haplotype diversity, but the CJ population showed low diversity and its Tajima's D value was significantly high (Table 2), suggesting a demographic history of population contraction. Since the CJ population is located at a tourist site (Cheonjiyeon waterfall), where a thin managed forest exists along the stream, human disturbances may reduce the diversity and population size, as reported for other lichens $[64,69]$. 
The AMOVA result for the geographic group showed significant differentiation between populations that were also subdivided within individual tree stands (Table 3). In contrast, the host plant did not influence the haplotype composition. This result coincides with the case of epiphytic lichen (Ramalina menziesii), which showed a similar population structure among the host plant $[11,66]$. These results indicate that $S$. multiformis populations on Jeju Island have great diversity within the population and are highly differentiated by geography. Based on DAPC analysis, the genetic structure was divided into the northern and southern areas (Figure 4). This population differentiation, depending on the longitudinal gradient, may be associated with the close geographical distance or similar environmental conditions. On the other hand, the effects of the geographic distance (IBD) and environmental difference (IBE) on the population differentiation were not detected in the $S$. multiformis populations. The IBD pattern has been found depending on the lichen species; Cetradonia linearis, Parmelina carporrhizans, and Parmelina tiliacea showed IBD patterns $[17,18,70]$. The different pattern of IBD may be associated with dispersal mechanisms. Generally, sexual propagules (e.g., ascospores) can disperse over long distances, whereas asexual propagules (e.g., isidia, soredia, and conidia) only disperse over a short range [71-74]. S. multiformis can make ascospores, while it is rare for it to produce abundant conidia [22]. Therefore, the long distance between habitats may obstruct the dispersal success due to the capacity of conidia dispersal, which may exceed the scale of the IBD pattern. Environmental variables also did not explain the genetic distance of S. multiformis populations, which is different from that of other lichen species. The IBE pattern of climatic variables (e.g., temperature and precipitation) have been detected in Cetradonia linearis, Nephroma laevigatum, and Parmelina tiliacea $[17,19,68]$. The IBE pattern was not detected in S. multiformis populations possibly because of a lack of relevant environmental variables. In this analysis, the macroclimatic variables from WorldClim were used, but the microclimate (e.g., sampling height or distance from the river) can be important to lichens $[19,75]$. In addition, the genotype specificity of photobiont can influence the genotype of the lichen populations [76-78].

The high genetic differentiation of $S$. multiformis populations may be influenced by the habitat availability. The low level of habitat availability due to forest fragmentation and deforestation can lead to a restriction of gene flow between populations $[79,80]$. In the center of Jeju Island, forests are highly connected among Mt. Halla. In lowland areas, however, the forests are restricted to a small area and are disconnected [81]. Given that host plant availability is the most important factor affecting Strigula distribution (Figure 2b), the disconnected forests in lowland areas mean that Strigula experiences a limitation of habitat, which means it is restricted geographically, resulting in a low level of gene flow. Under this condition, the genetic diversity can be reduced, and geography-specific genotypes can disappear easily if the habitat is destroyed.

\section{Conclusions}

The distribution and genetic structure of Strigula was examined on Jeju Island. Strigula species were rare and distributed in restricted regions. The forest availability made the greatest contribution to the potential niche prediction, followed by elevation and precipitation. Strigula multiformis populations had high genetic diversity specific to each location and were highly differentiated by geography. Generally, populations were divided into the northern and southern areas, whereas the factors associated with population differentiation were unclear. Considering the restricted area of the predicted habitats and high differentiation level, Strigula on Jeju Island may suffer from habitat limitation and fragmentation. Therefore, the mechanism for the environmental effects on the distribution and genetic structure of Strigula needs to be investigated to better understand the ecology of foliicolous lichen and conserve the Strigula community in South Korea.

Author Contributions: Conceptualization, S.-Y.O. and J.-S.H.; Methodology, S.-Y.O.; Validation, S.-Y.O.; Formal analysis, S.-Y.O.; Investigation, S.-Y.O. and J.-J.W.; Resources, J.-S.H.; Data curation, S.-Y.O. and J.-J.W.; Writing-original draft preparation, S.-Y.O.; Writing—review and editing, S.-Y.O., J.-J.W., and J.-S.H.; Visualization, S.-Y.O.; Supervision, S.-Y.O. and J.-S.H.; Project administration, S.-Y.O. and J.-S.H.; Funding acquisition, J.-S.H. 
Funding: This study was supported by the project funded by the Korea National Arboretum (KNA1-1-22, 17-2), and the National Research Foundation of Korea (NRF-2018K1A3A1A13087249).

Conflicts of Interest: The authors declare no conflict of interest.

\section{Appendix A}

Table A1. Bioclimatic variables acquired from WorldClim database. The variables used in the analysis are marked with *

\begin{tabular}{cc}
\hline Code & Variable \\
\hline BIO01 * & Annual Mean Temperature \\
BIO02 & Mean Diurnal Range $($ Mean of monthly $($ max temp-min temp)) \\
BIO03 * & Isothermality (BIO02/BIO07 $\times 100)$ \\
BIO04 & Temperature Seasonality (standard deviation $\times 100)$ \\
BIO05 & Max Temperature of Warmest Month \\
BIO06 & Min Temperature of Coldest Month \\
BIO07 * & Temperature Annual Range $($ BIO05-BIO06) \\
BIO08 & Mean Temperature of Wettest Quarter \\
BIO09 & Mean Temperature of Driest Quarter \\
BIO10 & Mean Temperature of Warmest Quarter \\
BIO11 & Mean Temperature of Coldest Quarter \\
BIO12 * & Annual Precipitation \\
BIO13 & Precipitation of Wettest Month \\
BIO14 * & Precipitation of Driest Month \\
BIO15 * & Precipitation of Wettest Quarter \\
BIO16 & Precipitation of Driest Quarter \\
BIO17 & Precipitation of Warmest Quarter \\
BIO18 & Precipitation of Coldest Quarter \\
BIO19 &
\end{tabular}

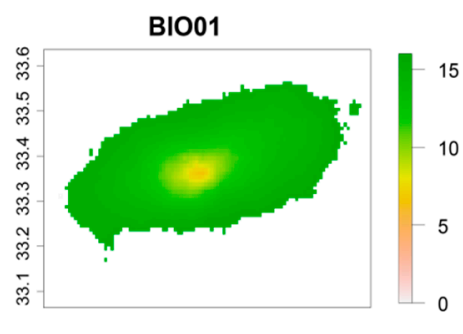

BIO12

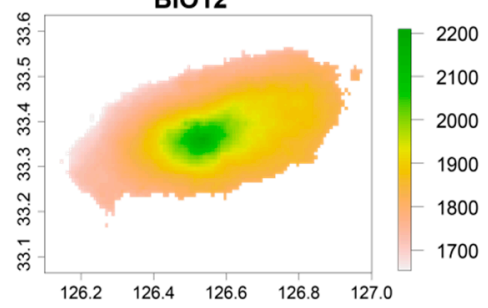

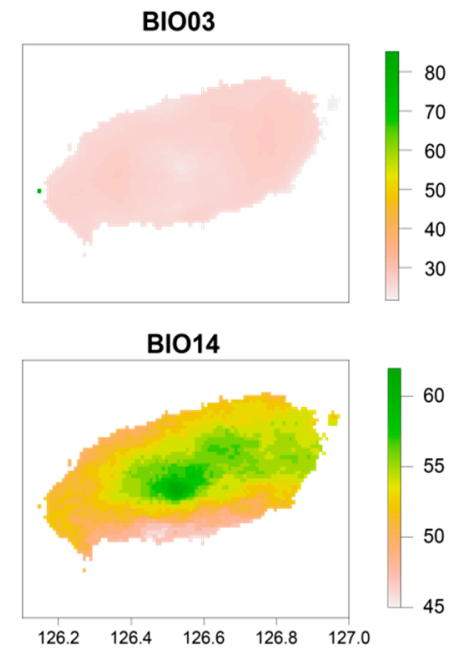

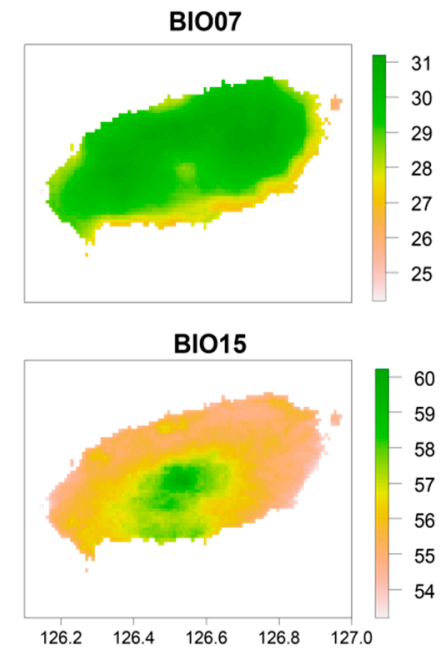

Figure A1. Bioclimatic variables on Jeju Island used for SDM analysis. Bioclim variables obtained from WorldClim database (BIO01: Annual mean temperature, BIO03: Isothermality, BIO07: Temperature annual range, BIO12: Annual precipitation, BIO14: Precipitation of the driest month, BIO15: Precipitation seasonality).

\section{References}

1. Farkas, E.E.; Sipman, H.J.M. Bibliography and checklist of foliicolous lichenized fungi up to 1992. Trop. Bryol. 1993, 7, 93-148.

2. Lücking, R. Foliicolous Lichenized Fungi; Flora Neotropica Monograph; Organization for Flora Neotropica and The New York Botanical Garden Press: Bronx, NY, USA, 2008; pp. 5-48. 
3. Sérusiaux, E. Foliicolous lichens: Ecological and chorological data. Bot. J. Linn. Soc. 1989, 100, 87-96. [CrossRef]

4. Lücking, R. Takhtajan's floristic regions and foliicolous lichen biogeography: A compatibility analysis. Lichenologist 2003, 35, 33-53. [CrossRef]

5. Glavich, D.A.; Geiser, L.H.; Mikulin, A.G. Rare epiphytic coastal lichen habitats, modeling, and management in the Pacific Northwest. Bryologist 2005, 108, 377-391. [CrossRef]

6. Bolliger, J.; Bergamini, A.; Stofer, S.; Kienast, F.; Scheidegger, C. Predicting the potential spatial distributions of epiphytic lichen species at the landscape scale. Lichenologist 2007, 39, 279-291. [CrossRef]

7. Cameron, R.P.; Neily, T.; Clayden, S.R. Distribution prediction model for Erioderma mollissimum in Atlantic Canada. Bryologist 2011, 114, 231-239. [CrossRef]

8. Dymytrova, L.; Stofer, S.; Ginzler, C.; Breiner, F.T.; Scheidegger, C. Forest-structure data improve distribution models of threatened habitat specialists: Implications for conservation of epiphytic lichens in forest landscapes. Biol. Conserv. 2016, 196, 31-38. [CrossRef]

9. Haughian, S.R.; Clayden, S.R.; Cameron, R. On the distribution and habitat of Fuscopannaria leucosticta in New Brunswick, Canada. Écoscience 2019, 26, 99-112. [CrossRef]

10. Ellis, C.J. Climate Change, Bioclimatic Models and the Risk to Lichen Diversity. Diversity 2019, 11, 54. [CrossRef]

11. Werth, S. Population genetics of lichen-forming fungi-A review. Lichenologist 2010, 42, 499-519. [CrossRef]

12. Mable, B.K. Conservation of adaptive potential and functional diversity: Integrating old and new approaches. Conserv. Genet. 2019, 20, 89-100. [CrossRef]

13. Razgour, O.; Forester, B.; Taggart, J.B.; Bekaert, M.; Juste, J.; Ibáñez, C.; Puechmaille, S.J.; Novella-Fernandez, R.; Alberdi, A.; Manel, S. Considering adaptive genetic variation in climate change vulnerability assessment reduces species range loss projections. Proc. Natl. Acad. Sci. USA 2019, 116, 10418-10423. [CrossRef] [PubMed]

14. Walser, J.-C.; Holderegger, R.; Gugerli, F.; Hoebee, S.E.; Scheidegger, C. Microsatellites reveal regional population differentiation and isolation in Lobaria pulmonaria, an epiphytic lichen. Mol. Ecol. 2005, 14, 457-467. [CrossRef] [PubMed]

15. Lindblom, L.; Ekman, S. Genetic variation and population differentiation in the lichen-forming ascomycete Xanthoria parietina on the island Storfosna, central Norway. Mol. Ecol. 2006, 15, 1545-1559. [CrossRef] [PubMed]

16. Sork, V.L.; Werth, S. Phylogeography of R amalina menziesii, a widely distributed lichen-forming fungus in western N orth A merica. Mol. Ecol. 2014, 23, 2326-2339. [CrossRef]

17. Núñez-Zapata, J.; Cubas, P.; Hawksworth, D.L.; Crespo, A. Biogeography and genetic structure in populations of a widespread lichen (Parmelina tiliacea, Parmeliaceae, Ascomycota). PLoS ONE 2015, 10, e0126981. [CrossRef]

18. Alors, D.; Dal Grande, F.; Cubas, P.; Crespo, A.; Schmitt, I.; Molina, M.C.; Divakar, P.K. Panmixia and dispersal from the Mediterranean Basin to Macaronesian Islands of a macrolichen species. Sci. Rep. 2017, 7, 40879. [CrossRef]

19. Belinchón, R.; Ellis, C.J.; Yahr, R. Climate-woodland effects on population genetics for two congeneric lichens with contrasting reproductive strategies. FEMS Microbiol. Ecol. 2018, 94, fiy159. [CrossRef]

20. Jayalal, U.; Oh, S.O.; Lücking, R.; Joshi, S.; Kim, J.A.; Park, J.-S.; Hur, J.-S. Contributions to the foliicolous lichens flora of South Korea. Mycobiology 2013, 41, 202-209. [CrossRef]

21. Lee, S.D.; Miller-Rushing, A.J. Degradation, urbanization, and restoration: A review of the challenges and future of conservation on the Korean Peninsula. Biol. Conserv. 2014, 176, 262-276. [CrossRef]

22. Woo, J.-J.; Lücking, R.; Oh, S.-Y.; Hur, J.-S. Two new species of foliicolous lichens in the genus Strigula (Strigulaceae, Strigulales), in Korea. Mycosphere 2019. under review.

23. Thor, G.; Lücking, R.; Matsumoto, T. The foliicolous Lichens of Japan; Symbolae Botanicae Upsalienses; Uppsala Universitet: Uppsala, Sweden, 2000; Volume 3, pp. 1-68.

24. Elith, J.; Leathwick, J.R. Species distribution models: Ecological explanation and prediction across space and time. Annu. Rev. Ecol. Evol. Syst. 2009, 40, 677-697. [CrossRef]

25. Hernandez, P.A.; Graham, C.H.; Master, L.L.; Albert, D.L. The effect of sample size and species characteristics on performance of different species distribution modeling methods. Ecography 2006, 29, 773-785. [CrossRef] 
26. Pearson, R.G.; Raxworthy, C.J.; Nakamura, M.; Townsend Peterson, A. Predicting species distributions from small numbers of occurrence records: A test case using cryptic geckos in Madagascar. J. Biogeogr. 2007, 34, 102-117. [CrossRef]

27. Wisz, M.S.; Hijmans, R.J.; Li, J.; Peterson, A.T.; Graham, C.H.; Guisan, A.; NCEAS Predicting Species Distributions Working Group. Effects of sample size on the performance of species distribution models. Divers. Distrib. 2008, 14, 763-773. [CrossRef]

28. Fick, S.E.; Hijmans, R.J. WorldClim 2: New 1-km spatial resolution climate surfaces for global land areas. Int. J. Climatol. 2017, 37, 4302-4315. [CrossRef]

29. Naimi, B.; Hamm, N.A.; Groen, T.A.; Skidmore, A.K.; Toxopeus, A.G. Where is positional uncertainty a problem for species distribution modelling? Ecography 2014, 37, 191-203. [CrossRef]

30. Jarvis, A. Hole-Field Seamless SRTM Data, International Centre for Tropical Agriculture (CIAT). 2008. Available online: http://srtm.csi.cgiar.org/ (accessed on 10 June 2019).

31. Dyer, R.J. Gstudio: Tools Related to the Spatial Analysis of Genetic Marker Data; R Package Version 1.5.2; 2016. Available online: http://dyerlab.github.io/gstudio/ (accessed on 15 May 2019).

32. Hijmans, R.J. Raster: Geographic Data Analysis and Modeling; R package Version 2.9-5;019. Available online: https://CRAN.R-project.org/package=raster/ (accessed on 15 May 2019).

33. Bivand, R.; Keitt, T.; Rowlingson, B. Rgdal: Bindings for the "Geospatial” Data Abstraction Library; 2019. Available online: https://CRAN.R-project.org/package=rgdal/ (accessed on 15 May 2019).

34. R Core Team. R: A Language and Environment for Statistical Computing. R Foundation for Statistical Computing: Vienna, Austria, 2018; Available online: https://www.R-project.org/ (accessed on 10 June 2019).

35. QGIS Development Team. QGIS Geographic Information System. Open Source Geospatial Foundation Project. 2019. Available online: http://qgis.osgeo.org/ (accessed on 10 June 2019).

36. Phillips, S.J.; Anderson, R.P.; Schapire, R.E. Maximum entropy modeling of species geographic distributions. Ecol. Model. 2006, 190, 231-259. [CrossRef]

37. Swets, J.A. Measuring the accuracy of diagnostic systems. Science 1988, 240, 1285-1293. [CrossRef] [PubMed]

38. Manel, S.; Williams, H.C.; Ormerod, S.J. Evaluating presence-absence models in ecology: The need to account for prevalence. J. Appl. Ecol. 2001, 38, 921-931. [CrossRef]

39. Rogers, S.O.; Bendich, A.J. Extraction of total cellular DNA from plants, algae and fungi. In Plant Molecular Biology Manual; Gelvin, S.B., Schilperoort, R.A., Eds.; Springer: Dordrecht, The Netherlands, 1994; pp. $183-190$.

40. White, T.J.; Bruns, T.; Lee, S.; Taylor, J.L. Amplification and direct sequencing of fungal ribosomal RNA genes for phylogenetics. In PCR Protocols: A Guide to Methods and Applications; Academic Press: New York, NY, USA, 1990; Volume 18, pp. 315-322.

41. Vilgalys, R.; Hester, M. Rapid genetic identification and mapping of enzymatically amplified ribosomal DNA from several Cryptococcus species. J. Bacteriol. 1990, 172, 4238-4246. [CrossRef] [PubMed]

42. Cuénoud, P.; Savolainen, V.; Chatrou, L.W.; Powell, M.; Grayer, R.J.; Chase, M.W. Molecular phylogenetics of Caryophyllales based on nuclear $18 \mathrm{~S}$ rDNA and plastid rbcL, atpB, and matK DNA sequences. Am. J. Bot. 2002, 89, 132-144. [CrossRef] [PubMed]

43. Lledo, M.D.; Crespo, M.B.; Cameron, K.M.; Fay, M.F.; Chase, M.W. Systematics of Plumbaginaceae based upon cladistic analysis of rbcL sequence data. Syst. Bot. 1998, 23, 21-29. [CrossRef]

44. Tamura, K.; Peterson, D.; Peterson, N.; Stecher, G.; Nei, M.; Kumar, S. MEGA5: Molecular Evolutionary Genetics Analysis Using Maximum Likelihood, Evolutionary Distance, and Maximum Parsimony Methods. Mol. Biol. Evol. 2011, 28, 2731-2739. [CrossRef] [PubMed]

45. Katoh, K.; Standley, D.M. MAFFT Multiple Sequence Alignment Software Version 7: Improvements in Performance and Usability. Mol. Biol. Evol. 2013, 30, 772-780. [CrossRef] [PubMed]

46. Rozas, J.; Ferrer-Mata, A.; Sánchez-DelBarrio, J.C.; Guirao-Rico, S.; Librado, P.; Ramos-Onsins, S.E.; Sánchez-Gracia, A. DnaSP 6: DNA sequence polymorphism analysis of large data sets. Mol. Biol. Evol. 2017, 34, 3299-3302. [CrossRef] [PubMed]

47. Bengtsson-Palme, J.; Ryberg, M.; Hartmann, M.; Branco, S.; Wang, Z.; Godhe, A.; De Wit, P.; Sánchez-García, M.; Ebersberger, I.; de Sousa, F.; et al. Improved software detection and extraction of ITS1 and ITS 2 from ribosomal ITS sequences of fungi and other eukaryotes for analysis of environmental sequencing data. Methods Ecol. Evol. 2013, 4, 914-919. [CrossRef]

48. Leigh, J.W.; Bryant, D. POPART: Full-feature software for haplotype network construction. Methods Ecol. Evol. 2015, 6, 1110-1116. [CrossRef] 
49. Clement, M.; Snell, Q.; Walke, P.; Posada, D.; Crandall, K. TCS: Estimating gene genealogies. In Proceedings of the 16th International Parallel and Distributed Processing Symposium IPDPS 2002, Ft. Lauderdale, FL, USA, 15-19 April 2002; p. 184.

50. Tajima F Statistical method for testing the neutral mutation hypothesis by DNA polymorphism. Genetics 1989, 123, 585-595.

51. Excoffier, L.; Laval, G.; Schneider, S. Arlequin (version 3.0): An integrated software package for population genetics data analysis. Evolut. Bioinform. Online 2007, 1, 47-50. [CrossRef]

52. Jombart, T.; Devillard, S.; Balloux, F. Discriminant analysis of principal components: A new method for the analysis of genetically structured populations. BMC Genet. 2010, 11, 94. [CrossRef] [PubMed]

53. Jombart, T. adegenet: A R package for the multivariate analysis of genetic markers. Bioinformatics 2008, 24, 1403-1405. [CrossRef] [PubMed]

54. Oksanen, J.; Blanchet, F.G.; Friendly, M.; Kindt, R.; Legendre, P.; McGlinn, D.; Minchin, P.R.; O’Hara, R.B.; Simpson, G.L.; Solymos, P.; et al. Package “Vegan": Community Ecology Package. R Package Version 2.5-4. 2017. Available online: https://CRAN.R-project.org/package=vegan/ (accessed on 15 May 2019).

55. Slatkin, M. A measure of population subdivision based on microsatellite allele frequencies. Genetics 1995, 139, 457-463. [PubMed]

56. McCune, B.; Schoch, C.; Root, H.T.; Kageyama, S.A.; Miadlikowska, J. Geographic, climatic, and chemical differentiation in the Hypogymnia imshaugii species complex (Lecanoromycetes, Parmeliaceae) in North America. Bryologist 2011, 114, 526-544. [CrossRef]

57. Fritz, Ö.; Niklasson, M.; Churski, M. Tree age is a key factor for the conservation of epiphytic lichens and bryophytes in beech forests. Appl. Veg. Sci. 2009, 12, 93-106. [CrossRef]

58. Rivera-Aguilar, V.; Godínez-Alvarez, H.; Moreno-Torres, R.; Rodríguez-Zaragoza, S. Soil physico-chemical properties affecting the distribution of biological soil crusts along an environmental transect at Zapotitlán drylands, Mexico. J. Arid Environ. 2009, 73, 1023-1028. [CrossRef]

59. Wolseley, P.A.; Stofer, S.; Mitchell, R.; Truscott, A.M.; Vanbergen, A.; Chimonides, J.; Scheidegger, C. Variation of lichen communities with landuse in Aberdeenshire, UK. Lichenologist 2006, 38, 307-322. [CrossRef]

60. Hawksworth, D.L.; Rose, F. Qualitative scale for estimating sulphur dioxide air pollution in England and Wales using epiphytic lichens. Nature 1970, 227, 145-148. [CrossRef] [PubMed]

61. Hill, D.J. Experimental Study of the Effect of Sulphite on Lichens with Reference to Atmospheric Pollution. New Phytol. 1971, 70, 831-836. [CrossRef]

62. Aptroot, A.; Ferraro, L.I.; Lai, M.-J.; Sipman, H.J.M.; Sparrius, L.B. Foliicolous lichens and their lichenicolous ascomycetes from Yunnan and Taiwan. Mycotaxon 2003, 88, 41-47.

63. Humphrey, J.W.; Davey, S.; Peace, A.J.; Ferris, R.; Harding, K. Lichens and bryophyte communities of planted and semi-natural forests in Britain: The influence of site type, stand structure and deadwood. Biol. Conserv. 2002, 107, 165-180. [CrossRef]

64. Bradtka, J.; Moning, C.; Werth, S.; Dziock, F.; Ba, C.; Hothorn, T. Forest Ecology and Management Lichen diversity in temperate montane forests is influenced by forest structure more than climate. Ecol. Manag. 2009, 258, 745-751.

65. Lücking, R. Biodiversity and conservation of foliicolous lichens in Costa Rica. Mitteilungen Eidgenöss. Forschungsanstalt Für Wald Schnee Landschschaft 1995, 70, 63-92.

66. Werth, S.; Sork, V.L. Local genetic structure in a North American epiphytic lichen, Ramalina menziesii (Ramalinaceae). Am. J. Bot. 2008, 95, 568-576. [CrossRef] [PubMed]

67. Mattsson, J.E.; Hansson, A.C.; Lindblom, L. Genetic variation in relation to substratum preferences of Hypogymnia physodes. Lichenologist 2009, 41, 547-555. [CrossRef]

68. Fernández-Mendoza, F.; Domaschke, S.; García, M.; Jordan, P.; Martín, M.P.; Printzen, C. Population structure of mycobionts and photobionts of the widespread lichen Cetraria aculeata. Mol. Ecol. 2011, 20, 1208-1232. [CrossRef]

69. Scheidegger, C.; Bilovitz, P.O.; Werth, S.; Widmer, I.; Mayrhofer, H. Hitchhiking with forests: Population genetics of the epiphytic lichen Lobaria pulmonaria in primeval and managed forests in southeastern Europe. Ecol. Evol. 2012, 2, 2223-2240. [CrossRef] [PubMed]

70. Allen, J.L.; Mckenzie, S.K.; Sleith, R.S.; Alter, S.E. First genome-wide analysis of an endangered lichen reveals isolation by distance and strong population structure Running. Am. J. Bot. 2017, 105, 1-12. 
71. ARMSTRONG, R.A. Dispersal, establishment and survival of soredia and fragments of the lichen, Hypogymnia physodes (L.) Nyl. New Phytol. 1990, 114, 239-245. [CrossRef]

72. Werth, S.; Wagner, H.H.; Gugerli, F.; Holderegger, R.; Csencsics, D.; Kalwij, J.M.; Scheidegger, C. Quantifying dispersal and establishment limitation in a population of an epiphytic lichen. Ecology 2006, 87, 2037-2046. [CrossRef]

73. Gjerde, I.; Blom, H.H.; Lindblom, L.; Saetersdal, M.; Schei, F.H. Community assembly in epiphytic lichens in early stages of colonization. Ecology 2012, 93, 749-759. [CrossRef] [PubMed]

74. Ronnas, C.; Werth, S.; Ovaskainen, O.; Várkonyi, G.; Scheidegger, C.; Snäll, T. Discovery of long-distance gamete dispersal in a lichen-forming ascomycete. New Phytol. 2017, 216, 216-226. [CrossRef] [PubMed]

75. Nadyeina, O.; Dymytrova, L.; Naumovych, A.; Postoyalkin, S.; Werth, S.; Cheenacharoen, S.; Scheidegger, C. Microclimatic differentiation of gene pools in the Lobaria pulmonaria symbiosis in a primeval forest landscape. Mol. Ecol. 2014, 23, 5164-5178. [CrossRef] [PubMed]

76. Werth, S.; Scheidegger, C. Congruent Genetic Structure in the Lichen-Forming Fungus Lobaria pulmonaria and Its Green-Algal Photobiont. Mol. Plant Microbe Interact. 2012, 25, 220-230. [CrossRef] [PubMed]

77. Piercey-Normore, M.D. The lichen-forming ascomycete Evernia mesomorpha associates with multiple genotypes of Trebouxia jamesii. New Phytol. 2006, 169, 331-344. [CrossRef] [PubMed]

78. Widmer, I.; Dal Grande, F.; Excoffier, L.; Holderegger, R.; Keller, C.; Mikryukov, V.S.; Scheidegger, C. European phylogeography of the epiphytic lichen fungus Lobaria pulmonaria and its green algal symbiont. Mol. Ecol. 2012, 21, 5827-5844. [CrossRef] [PubMed]

79. Templeton, A.R.; Shaw, K.; Routman, E.; Davis, S.K. The Genetic Consequences of Habitat Fragmentation. Ann. Mo. Bot. Gard. 1990, 77, 13-27. [CrossRef]

80. Young, A.G.; Boyle, T.; Brown, T. The population genetic consequences of habitat fragmentation in plants. Trends Ecol. Evol. 1996, 11, 413-418. [CrossRef]

81. Kang, H.G.; Kim, C.S.; Kim, E.S. Human influence, regeneration, and conservation of the Gotjawal forests in Jeju Island, Korea. J. Mar. Isl. Cult. 2013, 2, 85-92. [CrossRef]

(C) 2019 by the authors. Licensee MDPI, Basel, Switzerland. This article is an open access article distributed under the terms and conditions of the Creative Commons Attribution (CC BY) license (http://creativecommons.org/licenses/by/4.0/). 